\author{
IRINA ADELGEJM \\ (D) https://orcid.org/0000-0001-5208-0848 \\ Rosyjska Akademia Nauk \\ Moskwa
}

\title{
Doświadczenie tanatyczne i przezwyciężenie trwogi tanatycznej w powieściach Olgi Tokarczuk Ostatnie historie i Anna In w grobowcach świata
}

\author{
The thanatic experience and overcoming thanatic fear in \\ Olga Tokarczuk's novels Final Stories \\ and Anna In in the Tombs of the World
}

\begin{abstract}
The author of the paper examines two novels by Olga Tokarczuk - Final Stories and Anna In in the Tombs of the World in terms of self-psychotherapeutic functions of these texts in the process of overcoming the thanatic fear in the contemporary civilisation, characterised by the lack of effective rites of passage. It analyses the link between artistic devices and specific self-psychotherapeutic processes (desensitization, mythodrama) which they serve.
\end{abstract}

Key words: Olga Tokarczuk, thanatic experience, thanatic fear, self-psychotherapy

Stosunek do śmierci to istotny element światopoglądu kształtowany w ciągu całego życia (lub akceptowany i przejmowany jako gotowa forma ze środowiska społecznego). Zygmunt Bauman nazywa pamięć o śmierci ,integralną częścią wszystkich życiowych funkcji”, lęk wobec śmierci - jedynym niewyczerpalnym i całkowicie odnawialnym zasobem naturalnym, wszystkie zaś kultury - „pomysłowymi wynalazkami stworzonymi z myślą o uczynieniu znośnym życia ze świadomością własnej śmiertelności” (Bauman 2008, 74, 56). Podobnie Jurij Łotman uważa mitologię, religię i sztukę za podsta-

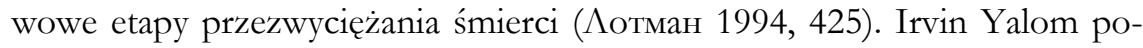
równuje strach tanatyczny do uśpionego wulkanu, „mrocznej, dręczącej obecności czającej się na krawędzi świadomości” (Я^ом 1999), Jean Baudrillard 
nazywa go „długim cieniem śmierci”, „fatalnością wpisaną w ludzkie ciało” (Бодрийяр 2006, 294).

Próby zapomnienia o tym cieniu, pragnienie wyparcia go ze świadomości i rzeczywistości - jako zjawiska, które wymyka się strategii pełnej kontroli nad życiem - paradoksalnie tylko zwiększają trwogę. Baudrillard, śledząc uważnie procesy, które doprowadziły współczesnego człowieka do bolesnego zaostrzenia strachu tanatycznego, nazywa współczesną kulturę „ciagłym wysiłkiem separacji życia i śmierci, ograniczania ambiwalencji śmierci, zastępowania jej jedynie reprodukcją życia jako wartości”, wskazuje na wyprowadzenie zmarłych „poza symboliczny obrót grupy”, a także na brak wymiany życia i śmierci w ramach cyklu społecznego (Болрийяр 2006, 264, 233-234).

Konsekwencje tego - naturalnego z psychologicznego punktu widzenia zjawiska są destrukcyjne właśnie dla psychiki indywidualnej: proces opisany przez Baudrillarda „uderza w żywych”, nasycając ich kulturę śmiercią i skazując na dożywotni lęk tanatyczny:

Gdy śmierć zostaje wyparta jako post-życie (...), życie jako takie staje się przetrwaniem zdeterminowanym przez śmierć. (...) [Z]a „,rzeczywistość” tego życia, za doświadczenie go jako wartości pozytywnej płacimy nieprzezwyciężalnym fantazmatem śmierci (Болрийяр 2006, 235, 245).

Współczesny człowiek po utracie dawnych - kolektywnych - mechanizmów wprowadzenia śmierci w symboliczny rytuał wymiany może jedynie odkupić śmierć poprzez osobiste przeżycie żałoby:

współczesny obraz śmierci zyskał swój ogólny wyraz w XVI wieku dzięki kontrreformacji, obsesyjnemu szaleństwu cmentarnemu w baroku, a zwłaszcza dzięki protestantyzmowi, który poprzez indywidualizację ludzkiej świadomości w obliczu Boga oraz mentalną dezinwestycję zbiorowych obrzędów nadał nowy impuls indywidualnemu strachowi przed śmiercią. Z niego wyrosła także potężna próba współczesnej epoki, by okiełznać śmierć. (...) śmierć ze szkieletu $\mathrm{z}$ kosą zamienia się w strach przed śmiercią (Болрийяр [Ś]mierć 2006, 262-263).

Ten uwolniony strach ciąży nad całym ludzkim życiem, ujawnia się na różnych jego etapach i w różnych okolicznościach, wzmagając się lub przeciwnie - zanikając w tle. Jednym z okresów, kiedy myśli o śmierci sa szczególnie bolesne, jest połowa życia. W latach 90. XX wieku młodych polskich prozaików niejednokrotnie posądzano o infantylizm (Czapliński 
2001, 222), jednak teksty następnej dekady, podejmujące temat śmierci, wymownie świadczą o naturalnym „dorastaniu”. Otóż misterna trzyczęściowa konstrukcja powieści Olgi Tokarczuk Ostatnie historie (2004) prezentuje cały system motywów tanatycznych: nie przypadkiem Magdalena Rabizo-Birek nazywa tę książkę „traktatem o śmierci” (Rabizo-Birek 2013, 157). Z kolei powieść Anna In w grobowcach świata (2006) inspirowana jest najstarszym z mitów o zejściu do królestwa zmarłych i jednocześnie jednym z pierwszych udokumentowanych dowodów strachu tanatycznego.

Ludzką percepcję śmierci można sprowadzić do trzech sytuacji tanatycznych, z których każda, niezależnie od dystansu i perspektywy, odsyła do głębokiego i zawsze indywidualnego lęku przed nieznanym i nieuniknionym: „Każda śmierć w swej banalności jest zawsze nowa (...), każdy naśladowca jest twórcą i odkrywca, każda kopia jest oryginałem, próba rozpoczęcia od nowa jest zawsze początkowa" (Янкелевич 1999, 13). Te trzy modele to: tragedia wyjątkowości, niepowtarzalności, podmiotowości pierwszej osoby („śmierć-ja”), następnie wielość i anonimowość trzeciej osoby („śmierć-on”), wreszcie doświadczenie drugiej osoby - śmierć kogoś bliskiego („śmierć-ty”) - znajdujące się pomiędzy „trzecią osobą, zasadą spokoju” a „pierwszą osobą, źródłem niepokoju” (Янкелевич 1999, 29) і łączące elementy ich obu.

Model „śmierci-ja” w literaturze jest próbą nadrobienia zawsze niepełnej dla żywej osoby znajomości śmierci1. O „śmierci-ja” opowiada pierwsza część Ostatnich historii. Ida, główna bohaterka, prawie od razu ginie w wypadku samochodowym. Narracja koncentruje się na pierwszym etapie przejścia ze świata żywych do świata umarłych, kiedy człowiek nie jest jeszcze świadomy własnej śmierci. Znaczace jest, że przed wypadkiem Ida widzi znak „Bożków-Bardo”, a następnie wybiera „kierunek najlepszy z możliwych (...), najbezpieczniejszy (...), gwarantujący dotarcie do celu” (Tokarczuk 2004, 9). Tym celem okazuje się w narracji śmierć. Będąc (autobiograficznym) elementem realnego krajobrazu, znak ten jednocześnie pełni rolę zwiastuna tragicznych wydarzeń, niezrozumianego przez bohaterkę ostrzeżenia przed śmiertelnym niebezpieczeństwem, a przede wszystkim odsyła do Tybetańskiej ksieggi umarlych i pojęcia „bardo”, nie po raz pierwszy pojawiającego się w twórczości Tokarczuk.

\footnotetext{
${ }^{1} \mathrm{Na}$ poziomie metody narracyjnej Michaił Bachtin nazywa ów model śmiercią „,z wewnątrz” lub „moją śmiercią”, w przeciwieństwie do śmierci „z zewnątrz” lub „śmierci innego" (Бахтин 1997, 347).
} 
Po wypadku Ida rzekomo wysiada z samochodu i dociera do dziwnej, na wpół opuszczonej osady. Jedyna ulica oświetlona „na fioletowo”2 (Tokarczuk 2004, 13) prowadzi bohaterkę do samotnego domu, w którym mieszkają starsi państwo opiekujący się umierającymi zwierzętami, czyli będący „przewodnikami” przy tym przejściu. Wypowiadają z pozoru banalne, lecz znaczące słowa: „Tyle ludzi przewinęło się już przez ten dom (...) i bez szyldu tu trafiają" (Tokarczuk 2004, 57). Oprócz aluzji do wspomnianej już Tybetanskiej ksiegi umarlych oraz id marcowych (czas zdarzeń to marzec, bohaterka nazywa się Ida Marc) charakterystyczna jest również symbolika ewangelijna (trzy dni spędzone przez Idę w dziwnym domu, kalendarz wiszący

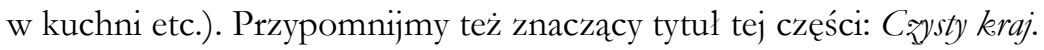

Ida czuje potrzebę opuszczenia domu, ale nie potrafi tego zrobić, choć nikt jej nie powstrzymuje (Tokarczuk 2004, 25, 56, 92). Ma dostęp do telefonu, ale zapomina, że miała zadzwonić albo odkłada ten moment, albo wreszcie nie może się dodzwonić; nie chce się jej jeść, jedzenie jest pozbawione smaku lub ma smak śmierci; nie widzi swojego odbicia lub nie do końca je rozpoznaje; cały czas wydaje się jej, że nie zauważyła czegoś bardzo ważnego - pewnie własnej śmierci, której przecież człowiek nie jest w stanie sobie uświadomić (Tokarczuk 2004, 27-28, 38, 55, 58, 85, 103). Ta część kończy się śmiercią jako taka: Ida opuszcza dziwny dom i wraca nie tylko na miejsce wypadku, ale jakby właśnie do tego momentu (Tokarczuk 2004, 117-118).

Doświadczeniem własnej śmierci - „nie jako wydarzenia”, lecz jako „mitu przeżytego zawczasu” (Бодрийяр 2006, 285) - jest w powieści (we wszystkich trzech częściach) obserwowanie przez bohaterki starzenia się ich ciał (Tokarczuk 2004, 38-39, 150, 252). Odkrycie tych zwiastunów śmierci, przeżywanie piętna starości jako śmierci symbolicznej okazuje się swego rodzaju spotkaniem ,ja” z „on”: „zderzeniem rozdwojonego podmiotu ze swym obiektywnym wizerunkiem" (Янкелевич 1999, 205).

Z kolei „śmierć-ty” to najbardziej dostępne doświadczenie śmierci, ponieważ nie będąc końcem własnego życia, sprawia jednak, że człowiek z przemożną moca przeżywa jej władzę: „Coś nieodwracalnego i niepowetowanego przydarza się mnie, coś pod tym względem podobnego do mojej własnej śmierci” (Bauman 2008, 78). Władimir Yankelevich określa to doświadczenie jako kolejny krok na drodze do poznania śmierci - drodze, którą jest całe życie ludzkie (Янкемевич 1999, 21).

2 Fioletowy to kolor symbolizujący przejście od aktywności do bierności, od życia do śmierci, związany z pokutą, czasem żałobą, zawsze tajemnicą. 
Stary Petro, bohater drugiej części powieści, umiera jeszcze przed rozpoczęciem narracji, której treścią staje się proces żałoby. Paraskewia, wdowa po Petrze, matka Idy, siedzi obok zmarłego; przypomina sobie ich wspólne życie, opowiada je na nowo zmarłemu i sobie; po raz kolejny dostrzega różnice pomiędzy nimi oraz możliwość alternatywnych kolei losu (Tokarczuk 2004, 128, 131, 134, 136, 139, 147, 150, 152, 153, 169, 177, 200). Faktyczna bliskość śmierci powoduje, że Paraskewia myśli o niej jako takiej, ale rdzeniem narracji jest stopniowe uświadomienie sobie odejścia męża (Tokarczuk 2004, 125, 133-134, 135, 141, 157, 168, 178). Wydeptywanie w śniegu liter tworzących frazę „Petro umarł!” jest zadaniem praktycznym (nie ma innego sposobu poinformowania mieszkańców doliny), ale staje się również symbolem tej refleksji. W obrazie Paraskewii i opisanego w tej części doświadczenia tanatycznego wyraźnie rysuje się charakter „śmierci-ty” jako sytuacji pośredniej pomiędzy śmiercią własną a obca. Z jednej strony tytułowa Parka jako zdrobnienie od imienia Paraskewia odsyła do bogiń losu; jej ostatnie słowa: „Stanę się częścią napisu. Zamienię się w punkt. Petro umarł!” (Tokarczuk 2004, 201) każą nam myśleć o niej jako o Morcie, trzeciej Parce, przecinającej nić losu ${ }^{3}$. Z drugiej zaś strony żałoba po mężu jest dla niej próbą własnej śmierci, coraz bardziej świadomego umierania wraz z Petro (Tokarczuk 2004, 134-135, 151, 157, 169, 177, 178, 189-190, 195, 199).

„Śmierć-ona”, śmierć w trzeciej osobie to „śmierć (...) abstrakcyjna i bezosobowa” (Янкелевич 1999, 29), pozostająca jednak budzącym grozę ostrzeżeniem, przypominającym lub poprzedzającym „śmierć-ty” i „śmierć-ja”. W powieści to zdarzenia opisane w trzeciej części: śmierć Sztukmistrza, przypadkowego znajomego Mai, córki Idy i wnuczki Paraskewii. Są to również związane ze śmiercią historie, przypuszczenia, sny, pajęczą nicią oplatające bohaterów i zdradzające pragnienie człowieka, by jej uniknąć, zawczasu ją rozpoznać, opóźnić, „udomowić” i tym samym zmniejszyć nieznośny strach (Tokarczuk 2004, 110, 114, 236, 247, 262).

„Śmierć-ty” i „śmierć-ona” opisane są w powieści Anna In w grobowcach świata. Autorka sięga do znanego z mitu sumeryjskiego wątku o zejściu bogini Inanny do świata podziemnego, wprowadzając tylko współczesne lub futurystyczne realia i dzieląc narracje pomiędzy kilka postaci mniej lub bardziej bliskich głównej bohaterce (zgodnie z tym jej tymczasową śmierć można interpretować jako „śmierć-ty” lub „śmierć-ona”).

$3 \mathrm{~W}$ tekście pojawia się również wątek tkactwa: Petro robi kilimy, ale zasadniczo ich twórczynią jest Paraskewia, która zauważa, że „w pewnym sensie jest to prawdą” (Tokarczuk 2004, 197). 
„Wszyscy umrzemy i powinniśmy się na to przygotować (...), żeby chociaż ten ostatni raz w życiu nie popełnić już błędu” (Tokarczuk 2004, 53) myśli bohaterka Ostatnich historii. W swoich utworach Tokarczuk usiłuje rekompensować brak skutecznych mechanizmów przezwyciężenia strachu tanatycznego we współczesnej kulturze ${ }^{4}$. To jeden ze sprawdzonych przez literaturę sposobów zdobycia doświadczenia niedostępnego w rzeczywistości - szczególnie pożądanego w czasach śmierci, która już nie jest „oswojona”, „intymnie związana z człowiekiem”, która stała się „dzika” (Арьеc, 1992), „infantylna”, która „zaniemówiła” (Бодрийяр 2006, 319).

Pierwotna trwoga śmierci zamienia się w maskowane lęki, powodujące nerwice, fobie i psychopatologie. Większość strategii adaptacyjnych budowanych przez ludzi w celu przezwyciężenia lęku przed śmiercią opiera się na negacji, wyparciu - ten mechanizm ochronny, który obraca się przeciwko człowiekowi, można obserwować na poziomie psychologii osobowej i zbiorowej (Бодрийяр 2006, 234, 315, 318; Сонтаг 2016, 11).

Według Irvina Yaloma skutecznym sposobem przezwyciężenia strachu tanatycznego, na który jest skazany człowiek we współczesnym społeczeństwie, zorientowanym na sukces i ignorującym śmierć, jest desensybilizacja: w Psychoterapii egzystencjalnej autor opisuje szereg ćwiczeń psychoterapeutycznych, które zmniejszają wskaźniki lęku przed śmiercią (Яıом 1999). Właśnie mechanizm desensybilizacji stosuje w Ostatnich historiach Tokarczuk.

Trzy bohaterki to trzy maski narratora. Potwierdzaja to słowa samej pisarki (wypowiedziane na spotkaniu w redakcji pisma „Inostrannaja Literatura” w Moskwie w 2006 roku), a także autobiograficzne szczegóły łączące bohaterki i mnóstwo oczywistych podobieństw między nimi (ААельгейм 2018, 465-474). Narrator jakby próbuje przyzwyczaić się do śmierci, oswajając ją za sprawą kilku kobiecych postaci - dzięki nałożeniu ludzkich masek (kobiet w różnym wieku, o różnym doświadczeniu i gotowości zaakceptowania nieuniknionego), masek zwierzęcych, poprzez maskaradę, odgrywanie śmierci w zabawach, fantazjach, na scenie itp. (ААельгейм 2018, 475-484).

Istotne znaczenie ma lustrzana konstrukcja narracji. Naturalny porządek spotkania ze śmiercią z reguły implikuje sekwencję „on” - „ty” - „ja”. Tokarczuk układa natomiast rozdziały w odwrotnej kolejności: personalizacja śmierci - doświadczenie „śmierć-ty” - przejście thanatos do paradygmatu

\footnotetext{
${ }^{4}$ Jak stwierdza Feifel, „nasz społecznie represyjny pogląd na śmierć wywołuje (...) neurotyczny niepokój. Edukacja i kultura powinny być przeniknięte bardziej bezpośrednim jej poznaniem" (Feifel 1969, 292).
} 
„śmierć-ona”. Jak twierdzi Bauman, „zniknięcie »osób trzecich« (obcych, pozbawionych twarzy i anonimowych »innych«) (...) nie uderzy w nas jako niepowetowana strata” (Bauman 2008, 77). W rzeczywistości jednak prawie każda taka śmierć pozostaje wymownym memento. Właśnie dlatego Sztukmistrz w trzecim rozdziale okazuje się być posłańcem śmierci, a jego zainteresowanie synem Mai przeraża bohaterkę: syn przestaje być dzieckiem, wchodzi w dorosły układ współrzędnych, z których jedną jest nieuchronna śmierć (Tokarczuk 2004, 267).

Pierwsza część powieści to zatem śmierć, druga to wiadomość o niej, trzecia to ścieżka do śmierci. „Odwrócona” kolejność rozdziałów jest zgodna z psychologicznym mechanizmem obronnym: przez całe życie „nakładając” na siebie śmierć, człowiek - na tyle, na ile to możliwe - odsuwa ja od siebie. Przerażenie przed ograniczonością ludzkiej egzystencji jest trwałe, nieprzemijające, ale póki się żyje, śmierć pozostaje w perspektywie przyszłości i choć ta niepewność wydaje się zbawcza, to jednak stale niepokoi. Narrator „nakłada” scenariusz śmierci na ,ja”, potem instynktownie ucieka w bezpieczniejsze „ty” i wreszcie w „on”, czyli od tragicznej podmiotowości pierwszej osoby poprzez drugą dąży do spokojnej anonimowości trzeciej.

Powieść jest skomplikowaną konstrukcją wielu łańcuchów śmierci - tak jak jest nią realne życie. Trzy części wiąże nie tylko doświadczenie „głównej”, fabułotwórczej lub tematotwórczej śmierci, spajaja je także inne z nią spotkania - to swego rodzaju katalog doświadczeń tanatycznych. Ponieważ chodzi o trzy pokolenia tej samej rodziny, łańcuchy śmierci mnożą się i przeplataja. „Śmierć-ja” (Ida) stanie się „śmiercią-ty” dla Mai. „Śmierć-ty” (Petro dla Paraskewii, sama Paraskewia, której śmierć jest obecna w narracji za sprawą wspomnień jej córki oraz wnuczki; Tokarczuk 2004, 84, 88-89, 262-263) stała się „śmiercią-on” dla Idy (jako śmierć rodziców, która niszczy ostatnią barierę, oddzielającą człowieka od własnej śmierci) i „śmiercią-on” dla Mai. Kontynuacja sekwencji „ja” - „ty” - „on” oznacza (hipotetycznie) „naturalny” porządek. Kolejny łańcuch to śmierć zwierząt. Otóż w pierwszej części schemat etapów spotkania ze śmiercią powtarza się w „naturalnym” porządku: kilka chwil przed wypadkiem leżący na poboczu martwy pies staje się nieodczytanym znakiem i przypomina o wiecznej obecności śmierci, potem w domu starszej pary umiera pies, który wydaje się Idzie „krewnym, niepokojąco podobnym” (Tokarczuk 2004, 113). Śmierć czworonoga przygotowuje bohaterkę do zaakceptowania własnego końca, który w rzeczywistości pewnie już nastąpił lub następuje. Charakterystyczne jest to, że właśnie w tym momencie Ida nagle odkrywa, iż została sama w domu 
- jak w obliczu własnej śmierci (Tokarczuk 2004, 112). Kiedy w końcu wraca na miejsce wypadku, odczuwa chęć przemienienia się w psa, który leżał przy drodze (Tokarczuk 2004, 118). „Śmierć-on” przekształca się więc w „śmierć-ty”, ta zaś przygotowuje się na śmierć własna. Świadczy o tym także sposób percepcji dwóch psów przez Idę. W pierwszym przypadku jest to ucieleśnienie tajemnicy, w drugim zaś wzrok umierającego zwierzęcia to wrota do tej tajemnicy (Tokarczuk 2004, 8, 18, 113). Ida próbuje pomóc konającemu stworzeniu (Tokarczuk 2004, 55, 65, 107, 108, 111) - to swoiste pokrewieństwo tych, co przekraczają ostatnią granicę. Wymowne są też liczne porównania zoomorficzne, związane z sytuacjami tanatycznymi.

W powieści pojawiają się różne zwiastuny śmierci: przede wszystkim słowa, które wydeptuje w śniegu Paraskewia, dzięki którym „zbocze przemówi” (Tokarczuk 2004, 200-201). Poza tym we wszystkich trzech rozdziałach spotykamy imię autorki - Olga. Noszą je postacie w różnym stopniu związane z głównymi bohaterkami i - zawsze - z zaświatami.

Powieść zawiera również szereg „,przymiarek” do śmierci. Są to wspomnienia Idy o dziecięcej zabawie w ,udawana śmierć”, związany ze śmiercią motyw „lalek”, dziecięce fantazje o własnej śmierci, „małe”, „próbne” śmierci, jak np. problemy z sercem czy poród (Tokarczuk 2004, 19-22, 37, 39-43, 100-101, 109, 128, 151, 179). Sztukmistrz w trzecim rozdziale umiera dwukrotnie ,na niby” i dopiero potem w rzeczywistości. Paraskewia myśli, że mąż „umarł na próbę, żeby zobaczyć, jak tam jest" (Tokarczuk 2004, 187-188).

Anna In jest próba przezwyciężenia trwogi śmierci za pomocą mitodramatu. „Doświadczanie” mitu pozwala odczuć w chaosie powszedniości obecność głębokiego porządku i harmonii, wzajemnych powiązań życia i śmierci oraz ocalającą całość wszechświata. Oparta na micie narracja ma zadanie terapeutyczne, kojąca moc mitu nie jest utracona ostatecznie:

„Wszystko już było” nie jako stan znudzonego umysłu współczesnego
człowieka, lecz jako odkrycie głębokiego porządku egzystencji. (...) Do-
tknąć mitu można było kiedyś dzięki emocjonalnemu przeżyciu, poprzez
rytualne w nim uczestnictwo (...). Jednak dziś, tak samo jak kiedyś, po-
trzebujemy starych mitów (...) żeby znów scalić świat, choćby za pomo-
cą cudzysłowu (Tokarczuk 2006, 217-218), czyli narracji.

Aleksjej Losiew nazywa mit „najbardziej konieczna, (...) transcendentalnie

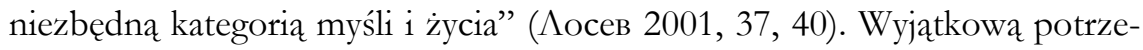
bę remitologizacji kultury Eleazar Mieletinski tłumaczy tym, że mit „aspiruje 
do rozwiązania" wielkich problemów metafizycznych, z którymi nie radzi sobie nauka (sens życia, tajemnica narodzin, śmierci, cel historii itp.; zob. Мелетинский 2001, 4).

Właśnie psychoterapeutyczne działanie mitodramatu umożliwia dotknięcie samej tkanki mitu - pozwala dostrzec go w realnym, codziennym życiu i wypracować metapozycję (Мапшина 2013, 4). Celem mitodramatu jest „studiowanie mitu od wewnątrz (...), utożsamiając się ze światopoglądem, uczuciami i motywacjami postaci, którą się odgrywa” (Бедненко 2006). Psychologiczne działanie mitu, na którym zasadza się utwór, Tokarczuk określa jako „rozbrojenie grozy śmierci” (Tokarczuk 2006, 209). Opowiadając historię umierania i buntu przeciwko śmierci, autorka nie reinterpretuje mitu, lecz doświadcza go razem z bohaterką, przekształcając powieść w swego rodzaju mitodramat, który pozwala na samoidentyfikację z główną bohaterką oraz kontakt emocjonalny z niedostępnym dla współczesnego człowieka w jego codziennym życiu sakramentem integralności wszechświata.

Właśnie temu służą realia modernizujące i futuryzujące mit, począwszy od transformacji imion bohaterów. Pragnienie doświadczenia mitu jest również powodem, dla którego Tokarczuk odwołuje się do okresu, „kiedy bogowie byli ludźmi”, do sumeryjskiej mitologii, w której „nie istniała jeszcze przepaść, która (...) podzieliła bogów i ludzi na dwa odrębne gatunki” (Tokarczuk 2006, 76, 99, 198). Inanna „poszła drogą ludzi, stała się jak oni, przetarła im droge" (Tokarczuk 2006, 107); wraz z boginią autorka i czytelnik przeżywają ludzkie doświadczenie: poczucie nieuchronności śmierci, jej „bezzasadności”, a zarazem „wszechzasadności”, obojętności świata żywych (Tokarczuk 2006, 19, 36, 37, 40, 49-50, 65, 68, 70, 73, 81, 145) itp. Śmierć jest tajemnicą nie tylko dla człowieka, lecz też dla bogów - ci ostatni są nieśmiertelni, więc ciekawi ich jej fenomen (Tokarczuk 2006, 126-127, 185). Jednocześnie narracja przypomina grę z postaciami komputerowymi, którym tak naprawdę nic nie zagraża: to przecież jest bunt bogini, nie ,jednorazowego" człowieka, który nie ma prawa bezkarnie przekroczyć progu, za którym można pokonać strach przed śmiercią (Tokarczuk 2006, 7, 21, 36, 40, 43-44, 97, 129). W mitodramacie to samo zjawisko zbiorowe zostaje przedstawione z odmiennych punktów widzenia - z perspektywy różnych uczestników. W powieści noblistki opowieść mityczna jest przekazywana z ust do ust (Tokarczuk 2006, 16, 30, 39, 55, 98, 112, 123, 125, 132-133, 137, 138, 140-141, 163, 173, 179, 190).

Narracja-mitodramat Tokarczuk to dosłowny podział bytu na dwie części - życie i śmierć - a następnie ponowne ich scalenie, doświadczenie śmierci 
jako integralnej i koniecznej części egzystencji. Życie i śmierć w powieści to nie tylko dwie strony tej samej monety, lecz bliźniaczki, które nie mogą żyć jedna bez drugiej; nie życie, lecz śmierć stanowi fundament świata w omawianym utworze jawi się jako jego zasadnicza podstawa (Tokarczuk 2006, 19, 31, 33, 36, 69, 168, 127, 119-120).

Nieśmiertelność jest nie tylko niemożliwa (Tokarczuk 2006, 194), ale też zbędna, ponieważ podstawą, a zarazem wartością bytu jest jego kruchość, nieodłączność od śmierci. Śmierć jest nieubłagana, ale jest też gwarancją jaskrawości doświadczenia życia, stąd oda do życia, którą wygłasza bogini śmierci, zwracając się do siostry (Tokarczuk 2006, 169). „Życie i śmierć są współzależne: fizycznie śmierć niszczy, ale idea śmierci nas ratuje. (...) Śmierć jest warunkiem, który pozwala nam żyć autentycznie" (ЯАOм 1999). Według Yankelevicha śmierć jest „widmem amorfizmu”, który zagraża ludzkiej egzystencji, ale „najbardziej paradoksalne” jest to, że właśnie „zagrożenie powrotu do bezkształtności” podtrzymuje napięcie życiowe, czyni życie „żywotnym” (Янкелевич 1999, 94), czyli ma funkcję formotwórcza.

Tę podwójną naturę świata, a zarazem paradoks ludzkiej psychologii mit pokazuje w całej swojej niedostępności dla człowieka współczesnego. Zatem celem sięgania po mit u Tokarczuk jest dążenie do harmonii, zaakceptowania śmierci jako elementu archaicznej wymiany między człowiekiem a przyrodą: „Przywrócenie śmierci do życia to fundamentalna operacja symbolicznego" (Бодрийяр 2006, 240). Doświadczenie mitu pozwala przynajmniej częściowo odbudować utracona przez człowieka zdolność do wpisania śmierci w symboliczny rytuał wymiany. Racjonalnie nie da się osiagnąć tego, co umożliwiały inicjacje i misteria:

Centralny moment operacji symbolicznej to inicjacja. Jej celem nie jest ograniczenie lub „przezwyciężenie” śmierci, lecz jej artykulacja społeczna. (...) [Ś]mierć staje się przedmiotem wzajemnej (...) wymiany między przodkami i żywymi i stanowi nie lukę, tylko relację społeczną między partnerami. (...) następuje przejście od śmierci naturalnej, przypadkowej i nieodwracalnej do śmierci darowanej i otrzymywanej, a zatem odwracalnej, „rozpuszczalnej” w trakcie wymiany społecznej (Бодрийяр 2006, 242-243).

Mit - za pomocą rytuałów - zapewnia ,utrzymanie harmonii osobistego, społecznego, naturalnego wsparcia i kontrolę porządku społecznego i kosmicznego”. Mieletinski nazywa to „skuteczną z punktu widzenia pragmatyki stroną kompleksu rytualno-mitologicznego" (Мелетинский 2001, 5). Мi- 
steria „stwarzały światu poczucie bezpieczeństwa” (Tokarczuk 2006, 210). Mitodramat, oparty na micie o zejściu do krainy umarłych, w pewnym sensie będący spadkobiercą misteriów, pozwala „obejść dookoła życie i śmierć oraz wstapić w symboliczną rzeczywistość wymiany” (Болрийяр 2006, 242).

W momencie śmierci przejawia się pewna transcendencja ludzkiej egzystencji i ograniczenie ludzkiego doświadczenia. „Nie można nauczyć się umierania (...). Absolutnie nie jesteśmy w stanie pogodzić się ze śmiercią” (Янкелевич 1999, 260-262). Śmierci nie można ogarnąć rozumem - „odmawia składania zeznań” (Аерридa 1999, 48), znajduje się poza prawdą, nie podlega logicznemu wyjaśnieniu. Własna śmierć w istocie jest niewyrażalna w języku - Jacques Derrida opatruje wyrażenie „moja śmierć” cudzysłowem (Аерриха 1999, 49), twierdząc, że jest to skrajny przypadek nieistnienia znaczenia. Yankelevich nazywa człowieka „marionetką z przebłyskami świadomości i umysłem wystarczająco jasnym, by być nieszczę́liwą" (Янкелевич 1999, 142-143). Każdy człowiek wykonuje ogromną pracę wewnętrzną, aby nauczyć się żyć ze strachem przed tym nieznanym i bronić się przed nim. Według Michela de Montaigne’a „nie możemy dotrzeć do samej twierdzy śmierci, ale możemy się do niej zbliżyć, rozeznać się w okolicy” (Монтень 1992, 215). Parafrazując Baumana, który również posługuje się metaforą bitewną, można powiedzieć, że chociaż nie da się osiągnąć ostatecznego zwycięstwa w nieustannej walce $\mathrm{z}$ tym lękiem, to jednak można wygrać wiele bitew (Bauman 2008, 95) i wcale nie ostatnią rolę - jak pokazuje przeprowadzona analiza - odgrywa tutaj słowo. Nie przypadkiem Tokarczuk, będąca z wykształcenia psychologiem, powiedziała o swojej powieści Ostatnie historie: „Poczułam się lepiej po tej książce i nawet gdyby nie została przeczytana ani zrozumiana, zaakceptowana, i tak spełniałaby swoje zadanie" (Tokarczuk 2004, on-line).

\section{Literatura}

Bauman Z., 2008, Plynny lęk, przeł. Margański J., Kraków.

Czapliński P., 2001, Wžnioste tesknoty. Nostalgie w prozie lat drienviéćdziesiatych, Kraków.

Feifel H., 1969, Attitudes toward death: A psychological perspective, "Journal of Consulting and Clinical Psychology", vol. 33 (3).

Rabizo-Birek M., 2013, Pierwsze i drugie crytanie „Ostatnich historii”, w: Rabizo-Birek M., Pocałuń-Dydycz M., Bienias A., red., Światy Olgi Tokarczuk, Rzeszów.

Tokarczuk O., 2004, Całe moje pisanie jest próba oswojenia præeczucia..., RMF Classic, http:/ $/$ www.rmfclassic.pl/7a $=$ wywiady\&id=1124\&npg=1 [dostęp: 20.01.2020]. 
Tokarczuk O., 2004, Ostatnie historie, Kraków.

Tokarczuk O., 2006, Anna In w grobowcach swiata, Kraków.

ААельгейм И.Е., 2018, Психология поэтики. Аутопсихотерапевтические функчии художественного текста. На материале польской прозы 1990-2010-х гг., Москва.

Арьес Ф., Человек перед личом смерти, http://krotov.info/history/18/general/e_1.htm [dostęp: 20.01.2020].

Бахтин М.М., 1997, 1961 год. Заметки, в: Бахтин М.М., Собрание сочинений в 7 m., т. 5, Москва.

Бедненко Г., 2006, Мифодрама: смысльи, чели, методъг. Аоклад, прочитанный на 4-й Московской психодраматической конференчии в апреле 2006 г., http://www.psychodrama.narod.ru/ text/bednenko_doklad.htm [dostęp: 20.01.2020].

Бодрийяр Ж., 2006, Символический обмен и смерть, Москва.

Аеррила Ж., 1999, Голос и феномен, Санкт-Петербург.

Аапшина Т., 2013, Ресурсы и ловушки мифологического мышиления: обзор работ Г.Б. Бедненко, „Журнал практического психолога”, № 2.

Аосев А.Ф., 2001, Аиалектика мифа, Москва.

Аотман Ю.М., 1994, Смерть как проблема сюжета, в: Ю.М. Аотман и тартуско-московская семиотическая школа, сост. Кошелев А.А., Москва.

Мелетинский Е.М., 2001, От мифа к литературе, Москва.

Монтень М., 1992, Опьтыз, Москва.

Сонтаг С., 2016, Болезнь как метафора, Москва.

ЯАом И., 1999, Экзистенщиальная психотерапия, http://www.psylib.ukrweb.net/books/yalo m01/index.htm [dostęp: 20.01.2020].

Янкелевич В., 1999, Смерть, Москва.

Irina Adelgejm - dr hab., Instytut Słowianoznawstwa Rosyjskiej Akademii Nauk, Moskwa, Rosja.

Autorka kilku monografii: Польская проза межвоенного двадиатилетия: между западом и Россией. Феномен психологического языка (Москва 2000), Поэтика "промежутка": молодая польская проза после 1989 года (Москва 2005), Психология поэтики: аутопсихотерапевтические функции художественного текста (на материале польской прозы 1990-2010 г2.) (Москва 2018) i wielu artykułów na temat literatury polskiej głównie XX i XXI wieku. Jej zainteresowania naukowe dotyczą literatury polskiej, a zwłaszcza prozy XX-XXI w., psychologii twórczości, związków literatury i pamięci oraz literatury i traumy. Tłumaczka dzieł takich twórców, jak: G. Herling-Grudziński, T. Różewicz, M. Tulli, P. Huelle, A. Stasiuk, O. Tokarczuk, E. Kuryluk, M. Bieńczyk, H. Krall, J. Korczak, J. Hen, M. Wilk, W. Tochman i in.

Kontakt: adelgejm@yandex.ru 